\title{
Article
}

\section{Solvent-free crystallization of ZSM-5 zeolite on SiC foam as a monolith catalyst for biofuel upgrading}

\author{
Qiuyan Zhu a, Yeqing Wang a,*, Lingxiang Wang a , Zhiyuan Yang a , Liang Wang b, Xiangju Meng a, \\ Feng-Shou Xiao a,b,\# \\ a Key Laboratory of Applied Chemistry of Zhejiang Province, Department of Chemistry, Zhejiang University, Hangzhou 310028, Zhejiang, China \\ ${ }^{\mathrm{b}}$ Key Laboratory of Biomass Chemical Engineering of Ministry of Education, College of Chemical and Biological Engineering, Zhejiang University, \\ Hangzhou 310028, Zhejiang, China
}

\section{A R T I C L E I N F}

\section{Article history:}

Received 29 September 2019

Accepted 29 October 2019

Published 5 July 2020

\begin{abstract}
A B S T R A C T
Conventional synthesis of monolith-supported zeolite catalysts is based on a hydrothermal strategy. Here, we report a solvent-free crystallization process to coat ZSM-5 zeolite crystals on a monolithic $\mathrm{SiC}$ foam with a honeycomb structure (ZSM-5/SiC). Characterizations of the ZSM-5/SiC by scanning electron microscopy, $\mathrm{N}_{2}$ sorption, and X-ray diffraction indicate that the zeolite sheath has been ideally coated on the surface of the SiC foam with high purity and crystallinity. Fixing Pd nanoparticles within the ZSM-5 zeolite crystals delivers a bifunctional Pd@ZSM-5/SiC catalyst, which exhibits high activity and selectivity toward diesel range paraffins in the hydrodeoxygenation of methyl oleate, a model molecule for biofuel. In comparison to the powder Pd@ZSM-5, the Pd@ZSM-5/SiC monolith catalyst shows more efficiency, which is attributed to the fast mass transfer and high heat conductivity on the honeycomb SiC structure. The durability test indicates that the Pd@ZSM-5/SiC catalyst is stable under the reaction and high-temperature regeneration conditions.
\end{abstract}

(C) 2020, Dalian Institute of Chemical Physics, Chinese Academy of Sciences. Published by Elsevier B.V. All rights reserved.

\section{Introduction}

Zeolite-based catalysts have been extensively used in fuel upgrading, pollutant removal, and fine chemical synthesis, because of their large surface areas, uniform microporous structures, suitable acidity, and rigid frameworks with outstanding thermal stability [1-11]. Generally, zeolite-based catalysts are localized in fixed-bed reactors in the form of powdered microgranules or extrudates, which are extensively used in the current practical processes, but the mass transfer on these catalysts still needs to be improved [12]. In most reactions, tem- perature differences in the reactor caused by limited heat transfer is also known to lead to unsatisfactory catalytic performance [13]. In order to overcome these problems, we investigate a promising strategy in which zeolite crystals are coated onto a monolith support.

A wide range of monolith carriers have been used to support catalysts, including alumina, cordierite, silicon carbide (SiC) honeycomb, and porous stainless steel [14-18]. In particular, the $\mathrm{SiC}$ has been regarded as an ideal support for catalysts due to several advantages, including high thermal conductivity, remarkable mechanical strength, and noteworthy resistance to

\footnotetext{
* Corresponding author. Tel/Fax: +86-571-88273698; E-mail: wangyeqing@zju.edu.cn

\# Corresponding author. Tel/Fax: +86-571-88273698; E-mail: fsxiao@zju.edu.cn

This work was supported by the National Key Research and Development Program of China (2018YFD1000806-01), National Natural Science Foundation of China (21822203, 91645105, 91634201), Natural Science Foundation of Zhejiang Province (LR18B030002), and the funding of central universities.
}

DOI: 10.1016/S1872-2067(20)63550-1 | http://www.sciencedirect.com/science/journal/18722067 | Chin. J. Catal., Vol. 41, No. 7, July 2020 
corrosion [19-21]. Pioneering studies carried out by coating zeolite-based catalysts onto an SiC matrix, reported remarkably enhanced catalytic performances for various reactions (e.g. methanol-to-olefin, methanol-to-gasoline, and dry reforming of methane), as compared to the powdered catalysts without the $\mathrm{SiC}$ carrier [22-35]. In particular, these materials were generally synthesized using the conventional hydrothermal route, a process that was realized by treating the $\mathrm{SiC}$ monolith in aqueous liquor for zeolite crystallization. This strategy is not very effective due to the production of undesirable wastes [36-41].

The present study demonstrates a new strategy for coating the zeolite sheath on the SiC carrier using solvent-free crystallization of zeolite. Employing MFI zeolite as a model, we rationally synthesized the MFI seed crystals, which were then coated on the SiC honeycomb monolith (ZSM-5/SiC). After fixing Pd nanoparticles within the zeolite sheath, the bifunctional Pd@ZSM-5/SiC catalyst was obtained, which is highly active, selective, and remarkably durable, when used in the hydrodeoxygenation of methyl oleate to obtain diesel range paraffins. Furthermore, the bifunctional Pd@ZSM-5/SiC catalyst is shown to consistently outperform the powder Pd@ZSM-5 catalyst, under equivalent reaction conditions.

\section{Experimental}

\subsection{Synthesis of ZSM-5/SiC and Pd@ZSM-5/SiC}

Prior to the solvent-free crystallization process, zeolite seeds were deposited on the $\mathrm{SiC}$ foam. Usually, $1 \mathrm{~g}$ of S-1 zeolite seeds were added into $50 \mathrm{~mL}$ of water under stirring, followed by adjusting the $\mathrm{pH}$ value to 10 with aqueous ammonia. After washing with ethanol and water, the $\mathrm{SiC}$ foam was immersed into the seed solution for $10 \mathrm{~min}$ and subjected to ultrasonic treatment. Subsequently, the $\mathrm{SiC}$ foam was dried at $100{ }^{\circ} \mathrm{C}$ for $12 \mathrm{~h}$.

The starting gel was prepared by mixing $1.2 \mathrm{~g}$ of $\mathrm{SiO}_{2}, 1.02 \mathrm{~g}$ of tetrapropylammonium hydroxide (TPAOH), $3.5 \mathrm{~g} \mathrm{H}_{2} \mathrm{O}$, and $0.015 \mathrm{~g}$ of boehmite under stirring at room temperature for $1 \mathrm{~h}$, followed by addition of the $\mathrm{SiC}$ foam on which the zeolite seeds had been implanted. After drying at $100{ }^{\circ} \mathrm{C}$ for $10 \mathrm{~min}$ to remove water partially, the coated $\mathrm{SiC}$ foam was transferred into an autoclave for heating at $180{ }^{\circ} \mathrm{C}$ for $3 \mathrm{~d}$. After calcining at 550

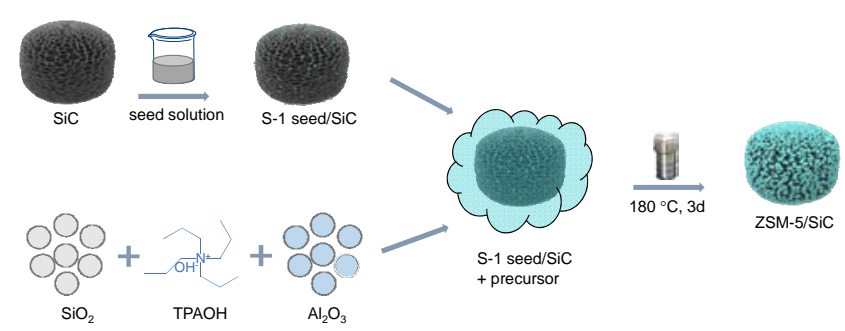

Fig. 1. Synthesis of ZSM-5/SiC.

${ }^{\circ} \mathrm{C}$ for $4 \mathrm{~h}$ in air, the ZSM-5/SiC was finally obtained. The Pd@ZSM-5/SiC was also prepared in a similar manner. The details for the synthesis of ZSM-5/SiC are schematically shown in Fig. 1.

\subsection{Hydrodeoxygenation of methyl oleate}

As a typical run, the solid catalyst containing $50 \mathrm{mg}$ of the zeolite component was placed within the reaction tube (titanium alloy, $50 \mathrm{~cm}$ in length, and with an internal diameter of 1 $\mathrm{cm})$. The methyl oleate was pumped in with a feed rate of 15 $\mathrm{g} / \mathrm{h}$ with a mixture of $\mathrm{N}_{2}$ and $\mathrm{H}_{2}$ gases ( $1 \mathrm{~atm}, 10 \% \mathrm{H}_{2}$ and $2 \%$ Ar in $\mathrm{N}_{2}, 30 \mathrm{~mL} / \mathrm{min}$ ). The reaction tube was heated by an oven and maintained at the desired reaction temperatures. Hot hydrazine at $200{ }^{\circ} \mathrm{C}$ was used to collect the heavy products, and the other products were directly analyzed online by a gas chromatograph (Shimadzu GC-2014C) with flame Ionization detector (FID) and thermal conductivity detector (TCD) with columns of HP-1, FFAP, and TDX-1. The offline products in the hot hydrazine were analyzed by the gas chromatograph using benzaldehyde and diphenyl as internal standards, while the online products were analyzed using Ar as the internal standard.

\section{Results and discussion}

\subsection{Synthesis and characterization}

Fig. 2(a) shows the X-ray diffraction (XRD) patterns of SiC, Pd@ZSM-5 powder, and Pd@ZSM-5/SiC. The pattern corresponding to Pd@ZSM-5 is that of a typical MFI structure
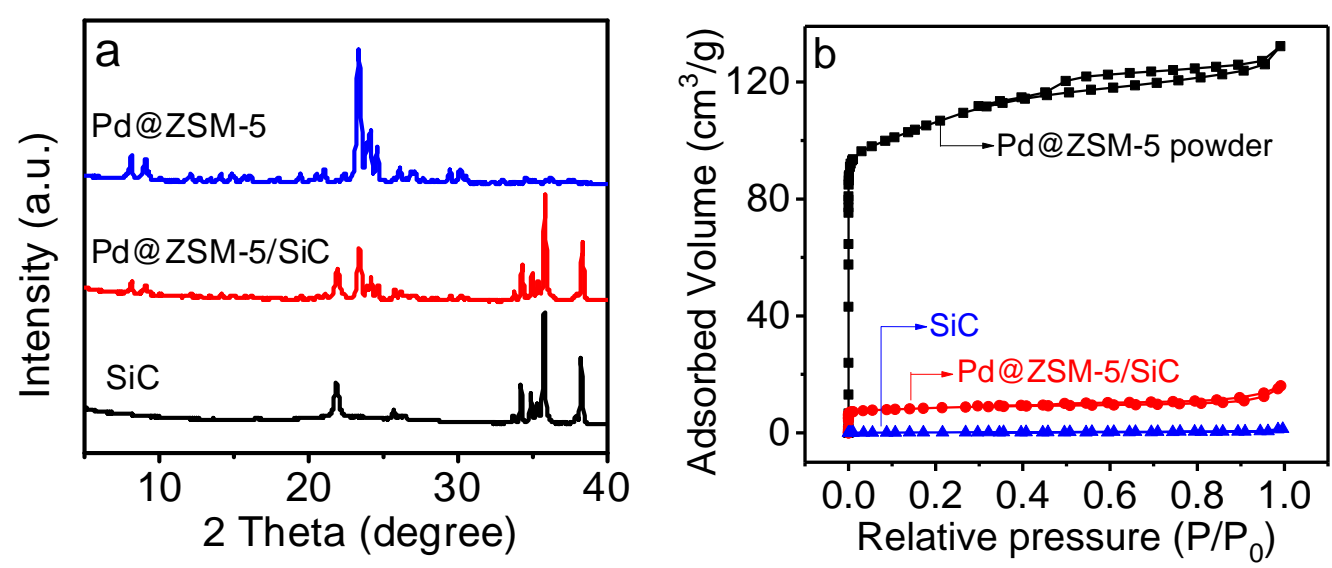

Fig. 2. XRD patterns (a) and $\mathrm{N}_{2}$ sorption isotherms (b) of SiC, Pd@ZSM-5 and Pd@ZSM-5/SiC. 
Table 1

Textural parameters of SiC, Pd@ZSM-5, and Pd@ZSM-5/SiC.

\begin{tabular}{lcccc}
\hline Sample & $\begin{array}{c}\text { BET surface } \\
\text { area }^{\mathrm{a}} \\
\left(\mathrm{m}^{2} / \mathrm{g}\right)\end{array}$ & $\begin{array}{c}\text { Pore } \\
\text { volume } \\
\left(\mathrm{cm}^{3} / \mathrm{g}\right)\end{array}$ & $\begin{array}{c}\mathrm{Pd}^{\mathrm{b}} \\
(\mathrm{wt} \%)\end{array}$ & $\begin{array}{c}\text { Zeolite } \\
\text { loading on SiC } \\
(\mathrm{wt} \%)\end{array}$ \\
\hline $\mathrm{SiC}$ & 1.5 & $<0.01$ & - & - \\
$\mathrm{Pd} @ Z \mathrm{ZSM}-5$ & 367.6 & 0.2 & 1.04 & - \\
$\mathrm{Pd@ZSM-5/SiC}$ & 31.6 & 0.03 & 1.02 & 12.3
\end{tabular}

a by $\mathrm{N}_{2}$ sorption measurement. ${ }^{\mathrm{b}}$ By inductively coupled plasma mass spectrometry (ICP) analysis.
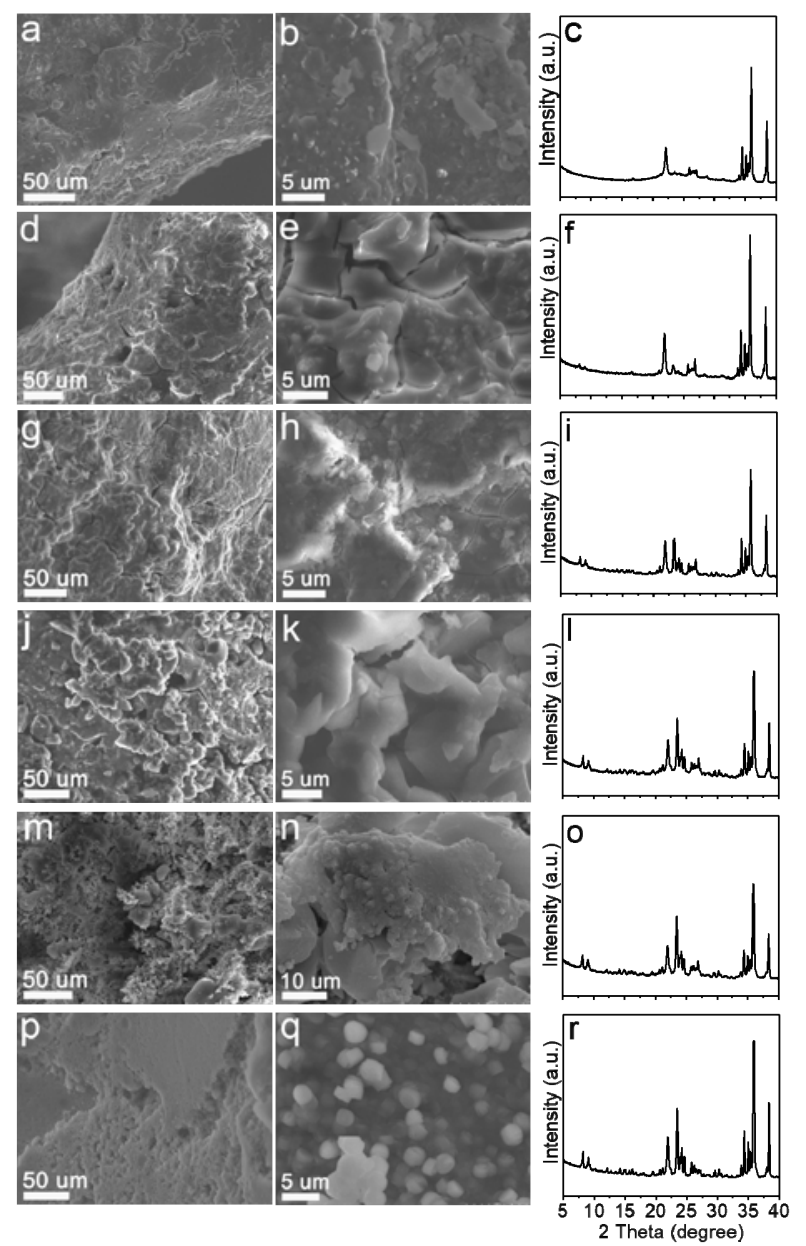

Fig. 3. SEM images and XRD patterns characterizing the ZSM-5/SiC crystallization process at different times. (a-c) $0 \mathrm{~h}$; (d-f) $30 \mathrm{~h}$; (g-i) $42 \mathrm{~h}$; (j-l) 54 h; (m-o) 66 h; (p-r) 72 h.

$[42,43]$. The SiC sample is observed to exhibit peaks of the dominant SiC phase [44]. The Pd@ZSM-5/SiC shows the XRD patterns of both SiC and MFI zeolite, in good agreement with that of the zeolite coated on the $\mathrm{SiC}$ support. Notably, the peaks corresponding to metallic Pd or PdO were completely undetectable in the XRD patterns due to the high degree of dispersion of the Pd nanoparticles.

Fig. 2(b) shows the $\mathrm{N}_{2}$ sorption isotherms of various samples. The Pd@ZSM-5 powder, which had a high degree of crystallinity in the sample, is seen to exhibit a type-I curve, which is characteristic of a microporous structure with high surface area $\left(367.6 \mathrm{~m}^{2} / \mathrm{g}\right)$ and pore volume $\left(0.20 \mathrm{~cm}^{3} / \mathrm{g}\right)$ (see Table 1$)$.
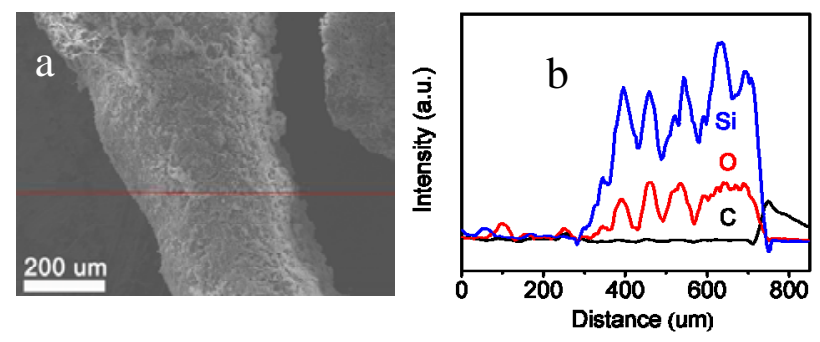

Fig. 4. Cross-section SEM image (a) and EDS linear analysis (b) of the ZSM-5/SiC sample.
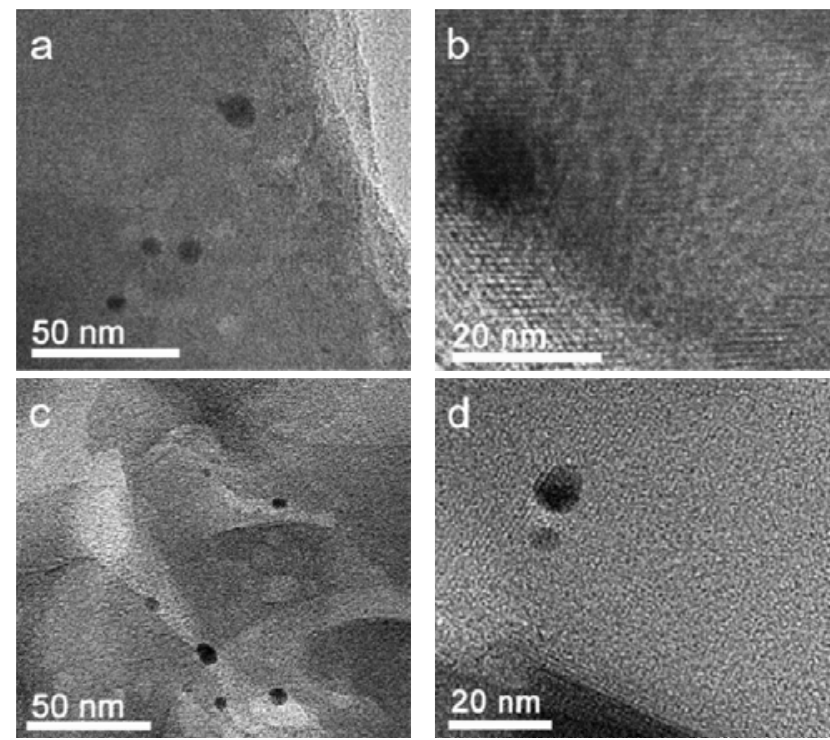

Fig. 5. TEM images of Pd@ZSM-5/SiC (a, b) and Pd@ZSM-5 (c, d).

The $\mathrm{SiC}$ is observed to be nonporous, with almost undetectable $\mathrm{N}_{2}$ adsorption, but Pd@ZSM-5/SiC is observed to have a higher surface area at $31.6 \mathrm{~m}^{2} / \mathrm{g}$ due to the presence of zeolite crystals. Based on the values for the pore volumes of Pd@ZSM-5, SiC, and Pd@ZSM-5/SiC, it is estimated that the ZSM-5 loading on the Pd@ZSM-5/SiC composite is about 12.3 wt\%.

The characterization of samples using scanning electron microscopy (SEM) and XRD (Fig. 3) affords a direct observation of the zeolite crystals coated on the SiC during the process of solvent-free crystallization. At the beginning of the crystallization process, only an amorphous phase is observed. After crystallization at $180{ }^{\circ} \mathrm{C}$ for $30 \mathrm{~h}$, a small quantity of irregular crystals can be observed in the SEM image, which is confirmed by the presence of very weak peaks in the XRD pattern of the sample. When the crystallization time is around $54 \mathrm{~h}$, obvious ZSM-5 crystals can be seen to appear in the sample. Beyond a crystallization time of $72 \mathrm{~h}$, there is no change in the XRD peak intensity and crystal size $(3 \mu \mathrm{m})$, suggesting that the process of crystallization of the ZSM-5 zeolite is complete.

Fig. 4 shows energy dispersive X-ray spectroscopy (EDS) linear analysis of the Pd@ZSM-5/SiC composite, displaying typical signals attributed to oxygen and silicon, with no signals corresponding to carbon, suggesting that the ZSM-5 zeolite is effectively coated on the surface of the SiC foam. Transmission electron microscopy (TEM; Fig. 5) enables direct observation of 


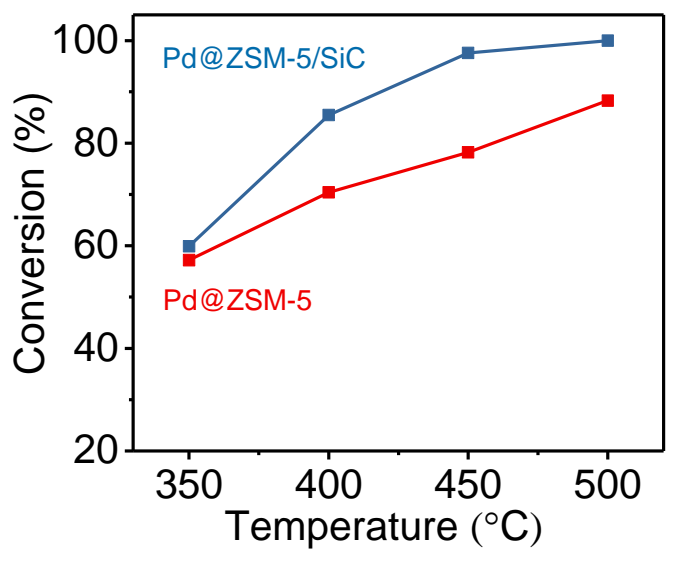

Fig. 6. Dependence of methyl oleate conversion on reaction temperature over Pd@ZSM-5/SiC and Pd@ZSM-5 catalysts.

the Pd nanoparticles present in the Pd@ZSM-5 and Pd@ZSM-5/SiC samples. The Pd nanoparticles are partly, but clearly seen in the zeolite region, indicating the effective fixation of Pd nanoparticles within the zeolite crystals. It is interesting to note that the Pd@ZSM-5 and Pd@ZSM-5/SiC samples exhibit similar Pd nanoparticle size distributions (8-10 nm).

\subsection{Catalytic activity}

The hydrogenation of methyl oleate to yield valuable al-
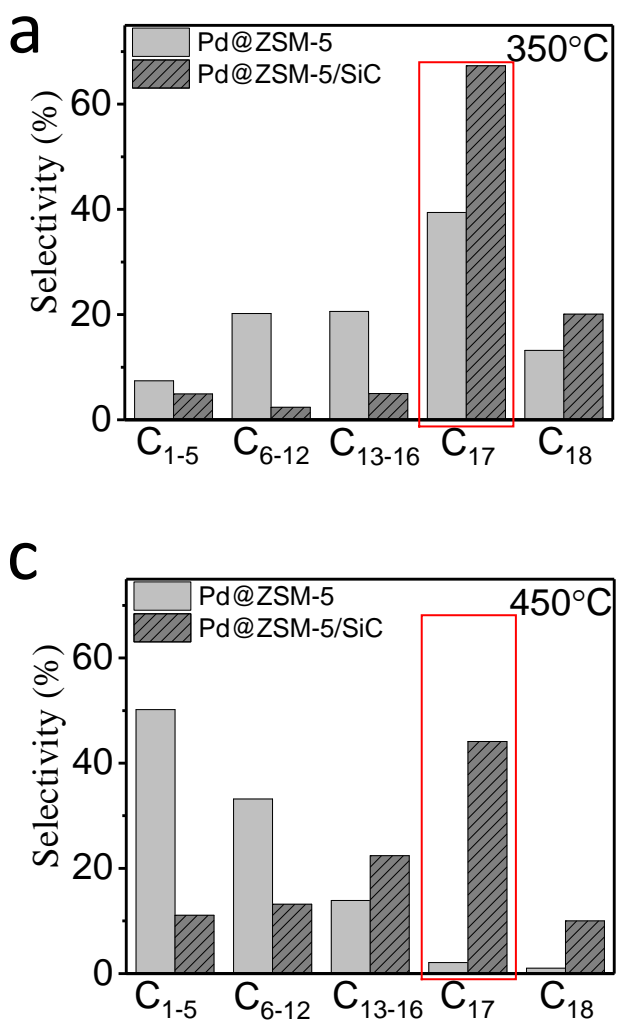

kanes over the Pd@ZSM-5 and the Pd@ZSM-5/SiC catalysts was carried out in a fixed-bed reactor. Fig. 6 shows the variation of the percentage conversion of methyl oleate and product selectivity with reaction temperatures between 350 and $500{ }^{\circ} \mathrm{C}$ over the Pd@ZSM-5 globular catalyst and the Pd@ZSM-5/SiC monolith catalyst, where the same amount of active components (Pd and zeolite) were employed. Under equivalent reaction conditions, the Pd@ZSM-5/SiC is always found to yield a higher percentage conversion than the Pd@ZSM-5. For example, at $450{ }^{\circ} \mathrm{C}$, the Pd@ZSM-5/SiC and Pd@ZSM-5 catalysts are found to exhibit methyl oleate conversions of $97.6 \%$ and $78.2 \%$, respectively. When the same reaction was carried out at $500{ }^{\circ} \mathrm{C}$, the Pd@ZSM-5/SiC catalyst is found to achieve complete conversion $(100 \%)$ of methyl oleate, whereas only an 88\% conversion is achieved over the Pd@ZSM-5 catalyst.

Apart from having distinct catalytic activities, the Pd@ZSM-5/SiC and Pd@ZSM-5 catalysts also exhibit different product selectivities in the hydrogenation reaction (Fig. 7). Long-chain hydrocarbon products are valuable, and therefore, desirable from the direct hydrodeoxygenation/decarboxylation of methyl oleate. However, the hydrocarbon cracking is known to usually yield less valuable low-carbon products. At $350{ }^{\circ} \mathrm{C}$, the Pd@ZSM-5/SiC catalyst promotes decarboxylation as the dominant reaction, with the following product selectivities: $67.3 \%$ and $20.1 \%$ of the desired $\mathrm{C}_{17}$ and $\mathrm{C}_{18}$ products, respectively and $2.4 \%$ and $5.0 \%$ of the undesired $\mathrm{C}_{6-12}$ and $\mathrm{C}_{13-16}$ products, respectively. In contrast, the Pd@ZSM- 5 shows selectivities of $39.4 \%$ and $13.2 \%$ for the desired $\mathrm{C}_{17}$ and $\mathrm{C}_{18}$ prod-
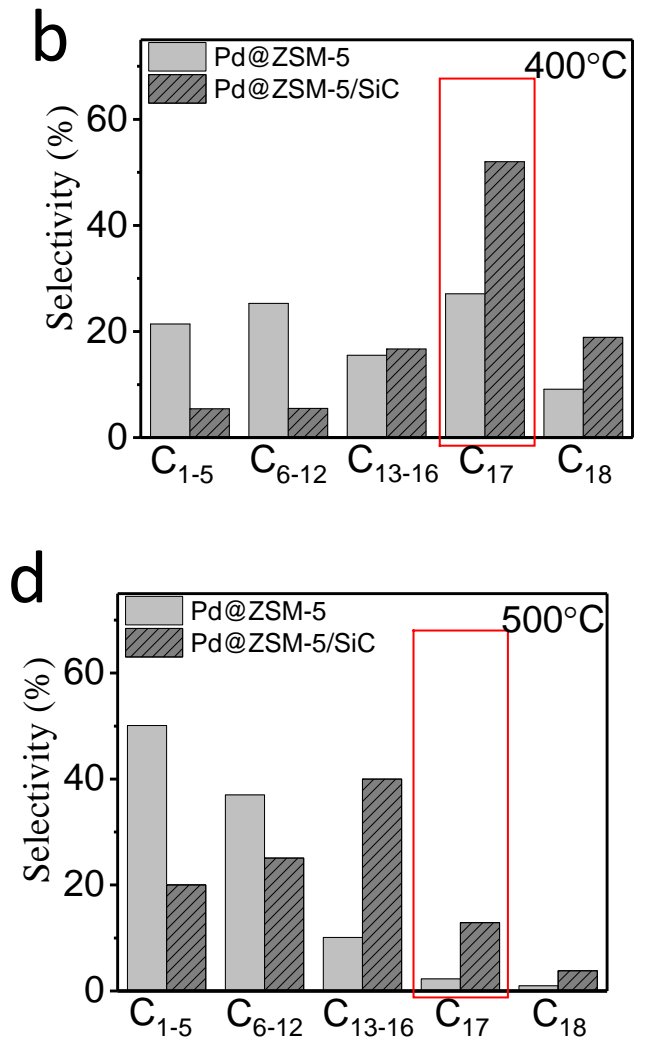

Fig. 7. The data characterizing the product selectivity of Pd@ZSM-5 and Pd@ZSM-5/SiC in the hydrodeoxygenation of methyl oleate at 350 (a), 400 (b), 450 (c), and $500{ }^{\circ} \mathrm{C}(\mathrm{d})$. 


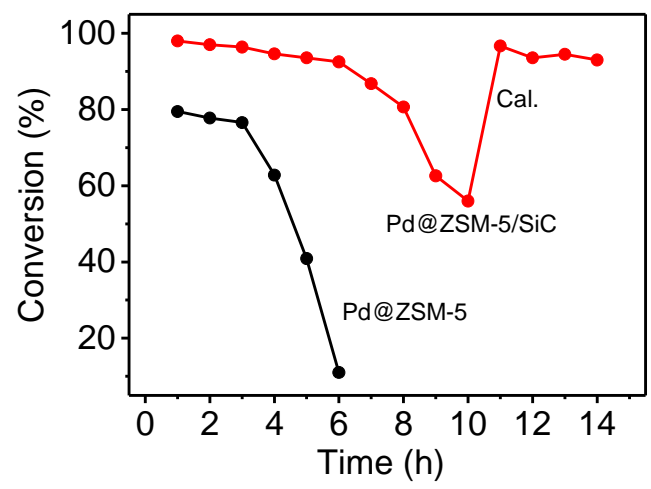

Fig. 8. Dependences of methyl oleate conversions on reaction time in the durability test over different catalysts. "Cal." denotes calcination at $450{ }^{\circ} \mathrm{C}$ in air to remove the coke.

ucts, respectively and $20.2 \%$ and $20.6 \%$ of the undesired $\mathrm{C}_{6-12}$ and $\mathrm{C}_{13-16}$ products, respectively. Clearly, the percentage yields of the desired valuable long-chain hydrocarbon products are much lower over the Pd@ZSM-5 than those over the Pd@ZSM-5/SiC catalyst. This phenomenon might be related to a significant enhancement of hydrocarbon cracking over the Pd@ZSM-5 catalyst, as confirmed by the higher selectivity towards low-carbon products. Notably, higher reaction temperatures accelerate the hydrocarbon cracking, but the Pd@ZSM-5/SiC remains the catalyst of choice to obtain long-chain products with high selectivity. For example, at 500 ${ }^{\circ} \mathrm{C}$, the cracking occurred as a dominant reaction over the Pd@ZSM-5 catalyst, giving $\mathrm{C}_{1-5}$ selectivity as high as $50.1 \%$ and C6-12 selectivity at 37.0\%. However, the Pd@ZSM-5/SiC catalyst maintains the $\mathrm{C}_{13-16}$ selectivity at $40.0 \%$, with $\mathrm{C}_{17-18}$ selectivity at $16.7 \%$.

The durability of the catalysts is evaluated in the continuous tests at $450{ }^{\circ} \mathrm{C}$ (Fig. 8). The catalytic activity over the Pd@ZSM-5 significantly decreases after a reaction time of $3 \mathrm{~h}$, losing more than $85 \%$ of the substrate conversions $(78.2 \%$ vs. 10.8\%). Under equivalent conditions, the Pd@ZSM-5/SiC catalyst shows stable activity until $6 \mathrm{~h}$; in fact, even after a reaction time of $10 \mathrm{~h}$, a $55.8 \%$ conversion is observed. The deactivation is attributed to coke formation because of the obvious color change observed for the used catalysts. The Pd@ZSM-5/SiC catalyst has a longer life compared to the Pd@ZSM-5, which is attributed to better coke resistance, and hence, faster mass transfer in the Pd@ZSM-5/SiC than that in the Pd@ZSM-5. Interestingly, the performance of deactivated Pd@ZSM-5/SiC catalyst could be completely regenerated in both methyl oleate conversion, as well as $\mathrm{C}_{17+}$ product selectivity (Fig. S5) by removing the coke through burning in air, demonstrating the high stability of the monolith catalyst under reaction and regeneration conditions.

These results demonstrate that the monolith catalyst can be used to efficiently obtain the valuable high-carbon products from the hydrodeoxygenation/decarboxylation reaction. The side reaction of hydrocarbon cracking is significantly suppressed over the monolith catalyst. In contrast, the conventional powder catalyst still exhibits high selectivity to the cracking products, in particular, for the reactions at higher temperatures. This can be rationalized by the presence of the zeolite crystals coated on the $\mathrm{SiC}$ matrix, which enable the fast mass transfer of relatively high carbon products to reduce the rate of the cracking reaction. In addition, the superior thermal conductivity of SiC might effectively reduce overheating on the catalyst in such an exothermic reaction, which also helps to suppress hydrocarbon cracking.

\section{Conclusions}

This work reports a zeolite coated $\mathrm{SiC}$ as a monolith platform for catalysis. In contrast to the previously developed hydrothermal route for coating zeolite crystals on the matrix, we present a solvent-free strategy to obtain the ZSM-5/SiC monolith catalyst. By embedding $\mathrm{Pd}$ nanoparticles into the ZSM-5/SiC matrix, the resultant Pd@ZSM-5/SiC catalyst is shown to exhibit high activity and excellent selectivity towards valuable long-chain paraffins in the upgrading of biofuel, by employing the methyl oleate-to-hydrocarbon transformation as a model. The Pd@ZSM-5/SiC monolith catalyst significantly outperforms the conventional powder Pd@ZSM-5 catalyst. This route holds a lot of promise for developing other monolith catalysts in the future.

\section{Acknowledgments}

Technical assistance, material support, and other help or advice may be acknowledged briefly in this section (excluding financial support, which should appear in the footnote on the title page).

\section{References}

[1] K. Cheng, B. Gu, X. Liu, J. Kang, Q. Zhang, Y. Wang, Angew. Chem. Int. Ed., 2016, 55, 4725-4728.

[2] C. Wang, E. Guan, L. Wang, X. Chu, Z. Wu, J. Zhang, Z. Yang, Y. Jiang, L. Zhang, X. Meng, B. C. Gates, F.-S. Xiao, J. Am. Chem. Soc., 2019, 141, 8482-8488.

[3] L. Zhang, L. Chen, Y. Li, Y. Peng, F. Chen, L. Wang, C. Zhang, X. Meng, H. He, F.-S. Xiao, Appl. Catal. B, 2017, 219, 200-208.

[4] E. Moradiyan, R. Halladj, S. Askari, Ind. Eng. Chem. Res., 2018, 57, 1871-1882.

[5] L. Guo, Y. Fan, X. Bao, G. Shi, H. Liu, J. Catal., 2013, 301, 162-173.

[6] Y. Wang, S. L. Chen, Y. L. Gao, Y. Q. Cao, Q. Zhang, W. K. Chang, J. B. Benziger, ACS Catal., 2017, 7, 5572-5584.

[7] M. Choi, Z. Wu, E. Iglesia, J. Am. Chem. Soc., 2010, 132, 9129-9137.

[8] M. Moliner, J. E. Gabay, C. E. Kliewer, R. T. Carr, J. Guzman, G. L. Casty, P. Serna, A. Corma, J. Am. Chem. Soc., 2016, 138, 15743-15750.

[9] N. Kosinov, C. Auffret, C. Gucuyener, B. M. Szyja, J. Gascon, F. Kapteijn, E. J. M. Hensen, J. Mater. Chem. A, 2014, 2, 13083-13092.

[10] C. S. Cundy, P. A. Cox, Chem. Rev., 2003, 103, 663-702.

[11] A. Corma, Chem. Rev., 1997, 97, 2373-2420.

[12] Y. Jiao, C. Jiang, Z. Yang, J. Zhang, Microporous Mesoporous Mater., 2012, 162, 152-158.

[13] S. Ivanova, C. Lebrun, E. Vanhaecke, C. Pham-Huu, B. Louis, J. Catal., 2009, 265, 1-7.

[14] G. B. F. Seijger, O. L. Oudshoorn, W. E. J. van Kooten, J. C. Jansen, H. 


\title{
Graphical Abstract
}

Chin. J. Catal., 2020, 41: 1118-1124 doi: 10.1016/S1872-2067(20)63550-1

Solvent-free crystallization of ZSM-5 zeolite on SiC foam as a monolith catalyst for biofuel upgrading

Qiuyan Zhu, Yeqing Wang *, Lingxiang Wang, Zhiyuan Yang, Liang Wang, Xiangju Meng, Feng-Shou Xiao* Zhejiang University

A solvent-free crystallization process is reported to coat the Pd@ZSM-5 zeolite crystals on a monolithic SiC foam to obtain a bifunctional Pd@ZSM-5/SiC catalyst. This monolith catalyst exhibits high activity and excellent selectivity towards the formation of diesel range paraffins in the hydrodeoxygenation of methyl oleate.

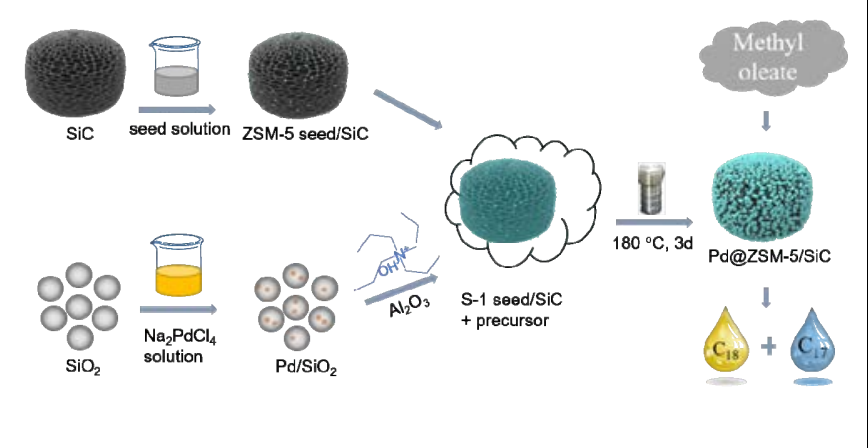

van Bekkum, C. M. van Den Bleek, H. P. A. Calis, Microporous Mesoporous Mater., 2000, 39, 195-204.

[15] J. Yao, C. Zeng, L. Zhang, N. Xu, Mater. Chem. Phys., 2008, 112, 637-640.

[16] I. Perdana, D. Creaser, I. Made Bendiyasa, Rochmadi, B. W. Tyoso, Chem. Eng. Sci., 2007, 62, 3882-3893.

[17] H. Kalipcilar, T. C. Bowen, R. D. Noble, J. L. Falconer, Chem. Mater., 2002, 14, 3458-3464.

[18] Y. Jiao, X. Yang, C. Jiang, C. Tian, Z. Yang, J. Zhang, J. Catal., 2015, 332, 70-76.

[19] M. Lacroix, P. Nguyen, D. Schweich, C. P. Huu, S. Savin-Poncet, D. Edouard, Chem. Eng. Sci., 2007, 62, 3259-3267.

[20] Y. Cui, X. Guo, Y. Wang, X. Guo, Chin. J. Catal., 2015, 36, 322-327.

[21] J. G. Fourie, J. P. D. Plessis, Chem. Eng. Sci., 2002, 57, 2781-2789.

[22] P. Losch, M. Boltz, K. Soukup, I. H. Song, H. S. Yun, B. Louis, Microporous Mesoporous Mater., 2014, 188, 99-107.

[23] X. Ou, S. Xu, J. M. Warnett, S. M. Holmes, A. Zaheer, A. A. Garforth, M. A. Williams, Y. Jiao, X. Fan, Chem. Eng. J., 2017, 312, 1-9.

[24] Y. Jiao, S. Xu, C. Jiang, M. Perdjon, X. Fan, J. Zhang, Appl. Catal. A, 2018, 559, 1-9.

[25] Z. Liao, T. Xu, Y. Jiang, B. Jiang, J. Wang, Y. Yang, Y. Jiao, Z. Yang, J. Zhang, Ind. Eng. Chem. Res., 2018, 58, 27-33.

[26] A. Zampieri, S. Kullmann, T. Selvam, J. Bauer, W. Schwieger, H. Sieber, T. Fey, P. Greil, Microporous Mesoporous Mater., 2006, 90, 162-174.

[27] S. Ivanova, B. Louis, M. J. Ledoux, C. Pham-Huu, J. Am. Chem. Soc., 2007, 129, 3383-3391.

[28] Y. Liu, S. Podila, D. L. Nguyen, D. Edouard, P. Nguyen, C. Pham, M. J. Ledoux, C. Pham-Huu, Appl. Catal. A, 2011, 409, 113-121.

[29] Y. Jiao, C. Jiang, Z. Yang, J. Liu, J. Zhang, Microporous Mesoporous Mater., 2013, 181, 201-207.
[30] S. Ivanova, B. Louis, B. Madani, J. P. Tessonnier, M. J. Ledoux, C. Pham-Huu, J. Phys. Chem. C, 2007, 111, 4368-4374.

[31] Q. Wei, G. Yang, Y. Yoneyama, T. Vitidsant, N. Tsubaki, Catal. Today, 2016, 265, 36-44.

[32] L. Gu, D. Ma, G. Hu, J. Wu, H. Wang, C. Sun, S. Yao, W. Shen, X. Bao, Dalton Trans., 2010, 39, 9705-9710.

[33] Q. Wei, G. Yang, X. Gao, N. Yamane, P. Zhang, G. Liu, N. Tsubaki, Chem. Eng. J., 2017, 327, 465-473.

[34] L. Gu, D. Ma, S. Yao, X. Liu, X. Han, W. Shen, X. Bao, Chem. Eur. J., 2009, 15, 13449-13455.

[35] S. Ivanova, E. Vanhaecke, B. Louis, S. Libs, M. J. Ledoux, S. Rigolet, C. Marichal, C. Pham, F. Luck, C. Pham-Huu, ChemSusChem, 2008, 1, 851-857.

[36] Y. Liu, S. Podila, D.L. Nguyen, D. Edouard, P. Nguyen, C. Pham, M. J. Ledoux, C. Pham-Huu, Appl. Catal. A, 2011, 409, 113-121.

[37] B. Louis, P. Reuse, L. Kiwi-Minsker, A. Renken, Appl. Catal. A, 2001, 210, 103-109.

[38] C. L. Kong, J. M. Lu, J. H. Yang, J. Q. Wang, J. Membr. Sci., 2006, 285, 258-264.

[39] Y. Y. Wang, G. Q. Jin, X. Y. Guo, Microporous Mesoporous Mater., 2009, 118, 302-306.

[40] C. D. Madhusoodana, R. N. Das, Y. Kameshima, A. Yasumori, K. Okada, Microporous Mesoporous Mater., 2001, 46, 249-255.

[41] M. M. Elamin, O. Muraza, Z. Malaibari, H. Ba, J. M. Nhut, C. Pham-Huu, Chem. Eng. J., 2015, 274, 113-122.

[42] H. Chen, X. Shi, J. Liu, K. Jie, Z. Zhang, X. Hu, Y. Zhu, X. Lu, J. Fu, H. Huang, S. Dai, J. Mater. Chem. A, 2018, 6, 21178-21185.

[43] P. Bai, P. Wu, W. Xing, D. Liu, L. Zhao, Y. Wang, B. Xu, Z. Yan, X. S. Zhao, J. Mater. Chem. A, 2015, 3, 18586-18597.

[44] H. Liu, S. Li, S. Zhang, L. Chen, G. Zhou, J. Wang, X. Wang, Catal. Lett., 2007, 120, 111-115.

\section{无溶剂法合成ZSM-5/SiC整体式催化剂制备生物燃料}

\author{
朱秋艳 ${ }^{\mathrm{a}}$, 王叶青年, 王凌翔 ${ }^{\mathrm{a}}$, 杨志远 ${ }^{\mathrm{a}}$, 王 亮 ${ }^{\mathrm{b}}$, 孟祥举 ${ }^{\mathrm{a}}$, 肖丰收, ${ }^{\mathrm{a}, \text {,\# }}$ \\ a 浙江大学化学系, 浙江省应用化学重点实验室, 浙江杭州 310028

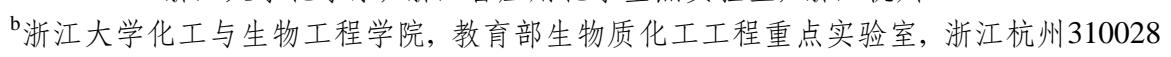

摘要: 传统合成整块载体负载分子節催化剂的方法是水热法, 这样往往伴随水资源浪费和釜内空间利用率低的问题. 本文 报道了应用无溶剂法在蜂窝结构的碳化硅(SiC)表面原位生长ZSM-5分子篮. 进一步采用该法将Pd纳米粒子限域在ZSM-5 
分子篮内, 合成Pd@ZSM-5/SiC双功能催化剂, 并在油酸甲酯加氢反应中表现出较高的活性和高碳烷烃选择性. 结果发现, Pd@ZSM-5/SiC表现出高选择性和耐久性, 这归因于 SiC优异的传质和导热特性.

$\mathrm{X}$ 射线衍射、扫描电子显微镜和氮气吸附等结果表明, 通过无溶剂法合成的分子篮具有很高的结晶度和纯度; 高分辨 透射电镜结果表明, 在Pd@ZSM-5和Pd@ZSM-5/SiC催化剂中, Pd纳米粒子均被良好封装, 并且粒径无明显差别, 因此排除 金属活性中心粒径的干扰.

油酸甲酯的直接加氢脱氧/脱羧可以制备具有高附加值的长链碳氢化合物, 而碳氢化合物的裂解通常会伴随着低碳化 合物等副产物的生成. 我们比较了两种催化剂在 $350-500{ }^{\circ} \mathrm{C}$ 的转化率和高碳烷烃的选择性差异. 在相同反应条件下, Pd@ZSM-5/SiC催化剂上油酸甲酯转化率始终高于Pd@ZSM-5. 例如在 $450{ }^{\circ} \mathrm{C}$, Pd@ZSM-5和Pd@ZSM-5/SiC的转化率分别 为 $97.6 \%$ 和 $78.2 \%$, 当温度提升至 $500{ }^{\circ} \mathrm{C}, \mathrm{Pd} @ Z S M-5 / \mathrm{SiC}$ 将油酸甲酯完全转化, 而Pd@ZSM-5的转化率仅为 $88 \%$. 在 $350{ }^{\circ} \mathrm{C}$ 时, Pd@ZSM-5/SiC 以脱羧反应为主, 其中 $\mathrm{C}_{17}$ 和 $\mathrm{C}_{18}$ 的选择性分别为 $67.3 \%$ 和 $20.1 \%, \mathrm{C}_{6-12}$ 和 $\mathrm{C}_{13-16}$ 选择性分别为 $2.4 \%$ 和 $5.0 \%$. 相比之下, Pd@ZSM-5催化剂 $\mathrm{C}_{17}$ 的选择性为 $39.4 \%, \mathrm{C}_{18}$ 的选择性为 $13.2 \%, \mathrm{C}_{6-12}$ 和 $\mathrm{C}_{13-16}$ 选择性分别为 $20.2 \%$ 和 $20.6 \%$. 由此可 见, Pd@ZSM-5对于高附加值的长链碳氢化合物的选择性远低于Pd@ZSM-5/SiC; 这可能与在Pd@ZSM-5催化剂上更容易 发生烷烃裂解副反应有关. 值得注意的是, 虽然升高温度会促进碳氢化合物的裂解, 但是在Pd@ZSM- $5 / S i C$ 催化剂上高碳 化合物依然较多. 例如, 在 $500{ }^{\circ} \mathrm{C}$ 时, 裂解是Pd@ZSM-5催化剂上的主要反应, $\mathrm{C}_{1-5}$ 的选择性高达 $50.1 \%, \mathrm{C}_{6-12}$ 的选择性高达 $37.0 \%$; 而在Pd@ZSM- $5 / \mathrm{SiC}$ 的产物中, $\mathrm{C}_{13-16}$ 的选择性为 $40.0 \%, \mathrm{C}_{17-18}$ 的选择性更是高达 $16.7 \%$. 此外, 在 $450{ }^{\circ} \mathrm{C}$ 的油酸甲酯 加氢连续实验中, Pd@ZSM-5/SiC比Pd@ZSM-5表现出更好的耐久性, 且催化剂失活后可以通过焙烧手段再生.

上述结果表明, Pd@ZSM-5/SiC催化剂有利于加氢脱氧/脱羧反应制备有价值的高碳烃产品, 更能抑制裂解副反应的进 行. 相比之下, 传统的粉末催化剂对裂解产物仍具有较高的选择性, 尤其是在较高的反应温度下. $\mathrm{SiC}$ 载体的引入有利于高 碳产物的传质, 从而抑制了裂解反应. 此外, 碳化硅良好的导热性可以有效地防止催化剂在反应中的过热, 同样有利于抑 制碳氢化合物的裂解.

关键词: 分子笁; Pd@ZSM-5/SiC; 整体式催化剂; SiC; 无溶剂法

收稿日期: 2019-09-29. 接受日期: 2019-10-29. 出版日期: 2020-00-05.

*通讯联系人. 电话/传真: (0571)88273698; 电子信箱: wangyeqing@zju.edu.cn

\#通讯联系人. 电话/传真: (0571)88273698; 电子信箱: fsxiao@zju.edu.cn

基金来源：国家重点研发计划(2018YFD1000806-01); 国家自然科学基金(21822203, 91645105, 91634201); 浙江省自然科学基金 (LR18B030002); 中央高校资助.

本文的电子版全文由Elsevier出版社在ScienceDirect上出版(http://www.sciencedirect.com/science/journal/18722067). 